\title{
Assessment of Ground Water Quality in Rajajinagar of Bangalore
}

\author{
ALIMUDDIN \\ Department of CS \& IT, Maulana Azad National Urdu University, \\ Gachibowli, Hyderabad- 32, India. \\ http://dx.doi.org/10.12944/CWE.10.1.40 \\ (Received: November 17, 2014; Accepted: January 05, 2015)

\begin{abstract}
Water borne diseases continue to be a dominant cause of water borne morbidities and mortality all over the world. Hence, drinking water needs to be protected from pollution and biological contamination. Ground water samples were collected from ten different sampling point in Rajajinagar area of Bangalore and analysed for water quality parameters viz. $\mathrm{pH}$, total alkalinity, chloride, total dissolved solids, electrical conductivity, sodium, potassium, calcium, magnesium, dissolved oxygen, $\mathrm{BOD}, \mathrm{COD}$ and total hardness. The $\mathrm{pH}$ value of the study area ranges between 7.3 to 8.4 indicating that ground water is slightly alkaline. The total alkalinity are varied in the range from 122 to 282 $\mathrm{mg} / \mathrm{l}$ which is well within the limit prescribed by BIS. The TDS value found from 397 to $546 \mathrm{mg} / \mathrm{l}$. The values of hardness of water ranges from 125 to $267 \mathrm{mg} / \mathrm{l}$ which is within the prescribed limit as per BIS.
\end{abstract}

Key words: Physico-chemical parameters, Ground water quality, Total alkalinity, Total hardness, TDS.

\section{INTRODUCTION}

Water is the most essential component for all living things. Living things cannot survive without water. It is one of the most essential constituents of the human environments. It is used for many purposes viz. drinking, irrigation, industrial water supply. It is also used for hydro- electric power generation. The quality of ground water varies from one place to another along with the depth of water table .it also changes with seasonal variation and is primarily governed by the extent and composition of dissolved solids present in it ${ }^{1}$. Drinking water needs to be protected from pollution and biological contamination. Underground water is clean but it depends upon quality and quantity of materials dispersed and dissolved in $i^{2}$. The reason for contamination and pollution of water in the surroundings and in the storage are pesticides, fertilizers, industrial wastes ${ }^{2}$.
The physico-chemical contaminants that adversely affect the quality of groundwater may be arises from a variety of sources, including land application of agricultural chemicals and organic wastes, infiltration of irrigation water, septic tanks ${ }^{3}$. Ground water quality is usually characterized by different physico-chemical characteristics. These parameters varies widely due to the various types of pollution, seasonal fluctuation and groundwater extraction $^{4}$

Therefore, a continuous monitoring on groundwater becomes essential in order to minimize the groundwater pollution have control on the pollution- caused agents.

\section{MATERIALS AND METHODS}

The city of Bangalore lies towards the southeast in the South Indian state of Karnataka. 
On the northeast of the city is Kolar District, on the northwest is Tumkur District, on the southwest is Mandya District and on the southeast is the state of Tamil Nadu. The geographical location of Bangalore city of India is such that it lies at an altitude of approximately $920 \mathrm{~m}$. Spread over an area of 2190 sq. $\mathrm{km}$, the city stands positioned at $12.97^{\circ} \mathrm{N} 77.56^{\circ}$ E.

Ground water samples were collected from 10 different sampling point. The samples for the routine analysis of parameters were collected in $500 \mathrm{ml}$ polyethylene bottles. The DO samples were collected in $250 \mathrm{ml}$ glass bottles. The samples for determining the BOD were collected in $250 \mathrm{ml}$ dark bottles. $\mathrm{pH}$ and conductivity $(\mu \mathrm{mhos} / \mathrm{cm})$ were determined at the site. The samples were analyzed using standard method, APHA $1995^{5}$

\section{RESULTS AND DISCUSSION}

The measure of concentration of ionized substances that convey electric current in water is known as electrical conductivity [6]. Conductivity is a good indicator to assess groundwater quality. EC were found within the range of 659 to $878 \mu$ mhos/ $\mathrm{cm}$.

The alkalinity indicates the presence of natural salts in water. The alkalinity is mainly due to the presence of carbonates, bicarbonates and hydroxides. The alkalinity values varied from 122 to $282 \mathrm{mg} / \mathrm{l}$ which is well within the limit prescribed by BIS.

The chloride found in the range between 34 to $125 \mathrm{mg} / \mathrm{l}$ which shows that all the samples is well within the prescribed limit of BIS. Cardiovascular diseases and taxemia in pregnant women ${ }^{7}$ is causes due to presence of high concentration of sodium in water. The sodium concentration ranges in between 97 to $114.5 \mathrm{mg} / \mathrm{l}$. Potassium content in the ground water samples varied from 1.2 to $4.6 \mathrm{mg} / \mathrm{l}$.

Calcium is a determinant of water hardness because it is found in water as $\mathrm{Cu}$ ions. Calcium varies in the ground water from 75 to $218 \mathrm{mg} / \mathrm{l}$. Almost all the samples were within maximum permissible limit as prescribed by the BIS.

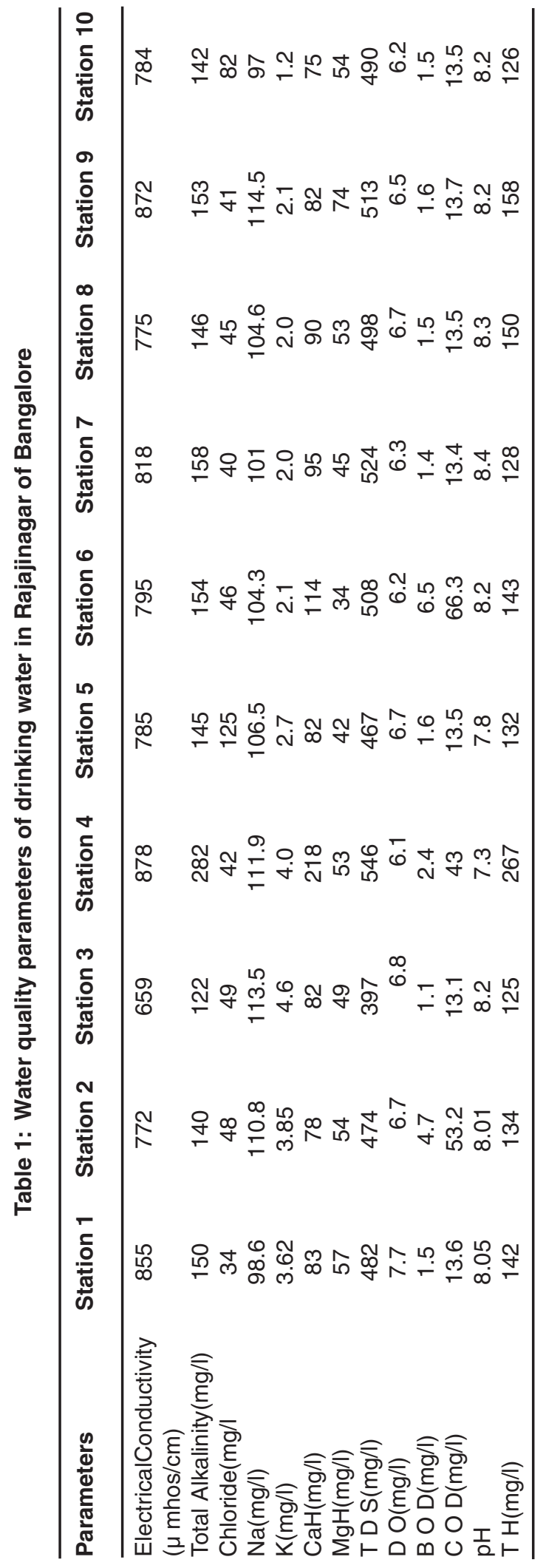


Magnesium comes up in water from many sources. Magnesium used in chemical industries to plastic and other materials as a fire protection measure or as filter. It also comes in the environment from fertilizer application and from cattle feed. The magnesium ranges from 34 to $57 \mathrm{mg} / \mathrm{l}$. TDS is the total concentration of cations and anions. Gastrointestinal diseases to the human beings are caused by the higher TDS value but the intake of water with the higher TDS for a long period of time can cause kidney stones and heart diseases ${ }^{8}$. The TDS value found from 397 to $546 \mathrm{mg} / \mathrm{l}$.

The dissolved oxygen (DO) enhances the quality of water and also acceptability. Dissolved oxygen (DO) of water under the area determined in the present investigation ranged between 6.1 to 7.7 $\mathrm{mg} / \mathrm{l}$. The BOD values determines the amount of organic waste present in the water ${ }^{9}$. The BOD values varied from 1.1 to $6.5 \mathrm{mg} / \mathrm{l}$.
The COD values indicates the amount of toxicity in water ${ }^{10}$. The COD values ranges from 13.1 to $66.3 \mathrm{mg} / \mathrm{l}$. The $\mathrm{pH}$ is the determination of hydrogen ions $[\mathrm{H+}]$ in water. Water with $\mathrm{pH}$ value below 7 is called acidic and water with a $\mathrm{pH}$ value above 7 is called basic in nature ${ }^{11}$. The $\mathrm{pH}$ ranges between 7.3 to 8.4 which is within prescribed limit as per BIS standard.

The property of water which prevents the lather formation with soap is known as hard water which increases the boiling point of water. The hardness of water conveys whether the water can be used for domestic, industrial or agricultural purposes or not? The hardness is caused due to the presence of excess of $\mathrm{Ca}$ and $\mathrm{Mg}$ salts. The values of hardness of water ranges from 125 to $267 \mathrm{mg} / \mathrm{l}$ which is within the prescribed limit as per BIS.

\section{REFERENCES}

1. Jain C.K, Bandyopadhyay A.and Bhandra A., J. Ind. Water Resource. Soc., 32(3-4), 8 ( 2012).

2. Tambekar D.H. and NewareB.B., Sci. Res. Reporter, 2(3): 229 (2012).

3. Pathak H. and Limaye S.N., Pelagia Res. Lib., 3(1): 555, (2012).

4. Srinivas G. and Nageswarrarao G., Arch. Environ.Sci. 7: 1 (2013).

5. American public health association, American water works association, water environment federation 1995

6. Kumar N. and Sinha D.K., Int. J. Environ. Sci.1:
253 (2010).

7. Shah M. C., Shilpkar P.G. and Achrarya P.B., E- J. Chem., 5(3), 435 (2008).

8. Garg et. al., Environ. Geol., 58: 1329 (2009).

9. Usharani et. al., J. Environ., Sci. and Environ. Mgmt., 14(2): 29 (2010).

10. Patil V.T. and Patil P.R., E-J. Chem., 8(1): 53 (2011).

11. Trivedi R. K. and Goel P. K., Chemical and Biological Methods for Water Pollution Studies, Environmental Publication, Karad, India, 1986. 